\title{
Prediction of mono and multiphasic growth parameters of broilers \\ (Short Communication)
}

\section{MEHMET MENDEŞ}

Biometry and Genetic unit 17020, Department of Animal Science, Faculty of Agriculture, Canakkale Onsekiz Mart University, Canakkale, Turkey

\section{Abstract}

The main objective of this study was to predict mono and multiphasic growth model parameters of broilers. For this purpose daily body weights-age data of 106 male and female chickens reared under different stocking densities (GR1=11 birds $/ \mathrm{m}^{2}, G R 2=17$ birds $/ \mathrm{m}^{2}$ and $\mathrm{GR} 3=25$ birds $/ \mathrm{m}^{2}$ ) were used. Results of mono and multiphasic (diphasic and triphasic) growth curve analyses showed that defining the growth of birds using multiphasic growth models instead of monophasic growth models, displays more detailed and reliable results. Based on goodness-of-fit criteria, lead to the choice of a triphasic logistic growth function for GR1 and GR2, and diphasic function for GR3 males and females.

Keywords: growth curve, multiphasic growth function, broiler

\section{Zusammenfassung}

\section{Vorausschätzung des Broilerwachstums mit Hilfe ein- bzw. mehrphasiger Wachstumsmodelle (Kurzmitteilung)}

Ziel der Studie war die Vorhersage des Wachstums bei Broilern mittels ein- bzw. mehrphasiger Wachstumsmodelle. Die zur Datenanalyse genutzten Tiere wurden in drei Gruppen bei unterschiedlicher Besatzdichte gehalten (GR1 $=11$ Tiere $/ \mathrm{m}^{2}, \mathrm{GR} 2=17 \mathrm{Tiere} / \mathrm{m}^{2}$ und $\mathrm{GR} 3=25 \mathrm{Tiere} / \mathrm{m}^{2}$ ). Ausgewertet wurden bei jeweils 53 männlichen und weiblichen Tieren die Körpergewichts- und Altersdaten. Sowohl für die männlichen als auch weiblichen Tiere wurden Kriterien für die Güte der Modellanpassung sowie die Ableitung von Wahlmöglichkeiten bei der Dreiphasen-Logistik-Wachtumsfunktion für die Gruppen GR1 und GR2 sowie der Zweiphasen-Funktion für GR3 beurteilt. Die Ergebnisse der einund mehrphasigen Wachstumskurvenanalyse zeigen, dass die Mehrphasenmodelle gegenüber dem einphasigen Wachstumsmodell detaillierte und zuverlässigere Ergebnisse anzeigen.

Schlüsselwörter: Wachstumskurve, mehrphasige Wachstumsfunktionen, Broiler 


\section{Introduction}

Models commonly used to describe growth of poultry include such as Von Bertalanffy, Gompertz, logistic, or Richards functions assume that growth is a monophasic, continuous process resulting in a near symmetric, S-shaped curve (WELLOCKT et al. 2004, ERSOY et al. 2006, MENDEŞ et al. 2007). However, in most animal species growth can be described by multiple S-shaped phases (multiphasic) due to seasonal fluctuations and differences in growth rates of body components (PIANTADOSI 1987). Multiphasic growth models were preferred to monophasic models to do better estimate of growth parameters in many studies (KOOPS 1986, KOOPS et al. 1987, KOOPS and GROSSMAN 1991, KOENEN and GROEN 1996, ÇAMDEVIREN and TAŞDELEN 2002, SORENSEN et al. 2003).

Multiphasic models were used to describe growth first in humans (BOCK and THISSEN 1976) and later in animals, such as mice (KOOPS 1986, KOOPS et al. 1987), turkeys (HURWITZ et al. 1991), chickens (GROSSMAN and KOOPS 1988), swine (KOOPS and GROSSMAN 1991), cattle (KOENEN and GROEN 1996), quail (ÇAMDEVIREN and TAŞDELEN 2002), and mink (SØRENSEN et al. 2003). Weight gain generally increases until maximum gain is reached, and then declines nearly symmetrically. The logistic function is often used to describe this symmetric growth pattern, which is why it is the basis for multiphasic growth models (PEIL and HELWIN 1981).

The main objective of this study was to predict mono and multiphasic growth parameters of broilers.

\section{Material and methods}

Data for this study came from 106 Ross 308 chickens divided into three groups based on stocking densities: one with 11 birds $/ \mathrm{m}^{2}$ stocking density (GR1: 11 males and 11 females), one with 17 birds $/ \mathrm{m}^{2}$ stocking density (GR2: 17 males and 17 females), and one with 25 birds $/ \mathrm{m}^{2}$ stocking density (GR3: 25 males and 25 females). Birds were reared through 49 days of age. The weekly body weights of males and females were collected from 1 weeks of age to 7 weeks of age.

\section{Statistical Analysis}

Multiphasic logistic function was fitted to body weight-age data of birds in each group and sex, where body weight (BW) for each phase i was modeled by:

$$
B W_{t}=\frac{a_{i}}{1+\exp \left(-\frac{t-c_{i}}{b_{i}}\right)}
$$

where $B W_{t}$ is the body weight $(\mathrm{g})$ at age $t$, and where for growth phase $i, a_{i}$ is the upper asymptotic body weight $(\mathrm{g})$ of the phase, $b_{i}$ is the measure of duration (weeks) of the phase (1/growth rate), $c_{i}$ is the time (days) of maximum increase (center) of the phase, exp is the base of the natural log (KOOPS 1986).

Therefore, total body weight (TBW) is the sum over phases: 


$$
T B W_{t}=\sum_{i=1}^{k}\left(\frac{a_{i}}{1+\exp \left(-\frac{t-c_{i}}{b_{i}}\right)}\right)
$$

where $k$ is the number phase. To account for the increase in variance with age, the multiphasic function was expressed in the natural log form (SØRENSEN et al. 2003):

$$
\ln \left(T B W_{t}\right)=\ln \left[\sum_{i=1}^{k}\left(\frac{a_{i}}{1+\exp \left(-\frac{t-c_{i}}{b_{i}}\right)}\right)\right]
$$

Firstly, 106 individual growth curves were fitted using the diphasic and the triphasic logistic growth models to test effect of stocking density (group), sex and group by sex interaction effect. Each parameter for the individual growth curves was then subjected to analysis of variance (PROC GLM, SAS Institute Inc. 1999), using the following model to test effects of group $(\alpha)$, sex $(\beta)$, and group by sex $(\alpha \beta)$ interaction:

$$
Y_{i j k}=\mu+a_{i}+\beta_{j}+a \beta_{i j}+\varepsilon_{i j k}
$$

where $Y_{i j k}$ is a growth curve parameter, $\mu$ is the overall mean, $a_{i}$ is the fixed effect of group $(i=1,2,3), \beta_{j}$ is the fixed effect of $\operatorname{sex}(j=1,2), a \beta_{i j}$ is the interaction effect between group and sex, and $\varepsilon_{i j k}$ is the residual error distributed as $\mathrm{N}\left(0, \sigma^{2}\right)$.

\section{Results}

Goodness-of-fit criteria were present in Table 1. The determination coefficient $\left(R^{2}\right)$ values were close to 1 , however there was a small increase in $\mathrm{R}^{2}$ when another phase was added. The standard error values reduced as another phase was added, as expected. The standard error values for three phases was considerably smaller than for one and two phases for GR1 and GR2 males and females. The Durbin-Watson statistics increased as another phase was added. When growth phase was increased two to three the DurbinWatson statistic tend to close 2 , indicating negligible autocorrelation.

\section{Monophasic logistic model}

The asymptotic or mature weight (a1) estimates of GR1 and GR2 males and females were similar when monophasic logistic function was used for describing the growth (Table 2). The a1 estimates for GR3 males were significantly higher than those of the GR1 and GR2, while the a1 estimates for GR3 females were smaller than those of the GR1 and GR2 $(P<0.05)$. Growth rate (b1) estimates of GR1 and GR2 males and females were similar. The b1 parameter estimates of GR3 males and females were higher than those of the GR1 and GR2. Similar situation was also valid for the age at maximum weight gain (c1) estimates in general. A positive autocorrelation, however, was observed when monophasic logistic function was used for describing growth (Table 1). 
Table 1

Goodness-of-fit criteria by group and sex for each phase

Güte der Modellanpassungskriterien für die mehrphasige Logistikmodelle nach Gruppen und Geschlecht

\begin{tabular}{lcccccccccc}
\hline $\begin{array}{l}\text { Phases } \\
\text { Group }\end{array}$ & Sex & SE & D-W & $\mathrm{R}^{2}$ & SE & D-W & $\mathrm{R}^{2}$ & SE & D-W & $\mathrm{R}^{2}$ \\
\hline \multirow{2}{*}{ GR1 } & Males & 0.058 & 0.31 & 0.989 & 0.015 & 1.06 & 0.999 & 0.005 & 1.97 & 0.999 \\
& Females & 0.052 & 0.38 & 0.988 & 0.019 & 0.88 & 0.999 & 0.007 & 1.47 & 0.999 \\
GR2 & Males & 0.039 & 0.52 & 0.991 & 0.024 & 1.73 & 0.999 & 0.013 & 1.73 & 0.999 \\
& Females & 0.044 & 0.48 & 0.992 & 0.021 & 1.46 & 0.999 & 0.010 & 1.75 & 0.999 \\
& Males & 0.025 & 0.46 & 0.999 & 0.013 & 1.88 & 0.999 & 0.011 & 2.10 & 0.999 \\
GR3 & Females & 0.036 & 0.38 & 0.999 & 0.019 & 1.53 & 0.999 & 0.015 & 1.87 & 0.999 \\
\hline
\end{tabular}

GR1 11 birds $/ \mathrm{m}^{2}$, GR2 $17 \mathrm{birds} / \mathrm{m}^{2}$, GR3 $25 \mathrm{birds} / \mathrm{m}^{2}$, SE standard error of mean, D-W Durbin-Watson statistic, $R^{2}$ determination coefficient

Table 2

Estimates of model parameters based on a monophasic logistic model Schätzung der Modellparameter auf der Grundlage des einphasigen Logistikmodells

\begin{tabular}{lcccc}
\hline Group & Sex & a1 & b1 & c1 \\
\hline \multirow{2}{*}{ GR1 } & Males & 2413.8 & 7.45 & 30.9 \\
& Females & 2406.9 & 7.78 & 32.0 \\
GR2 & Males & 2378.4 & 7.92 & 32.4 \\
& Females & 2401.1 & 7.90 & 32.6 \\
GR3 & Males & 2788.6 & 8.69 & 37.4 \\
& Females & 2157.8 & 8.45 & 33.2 \\
\hline
\end{tabular}

GR1 $11 \mathrm{birds} / \mathrm{m}^{2}$, GR2 $17 \mathrm{birds} / \mathrm{m}^{2}$, GR3 $25 \mathrm{birds} / \mathrm{m}^{2}$, a asymptotic or mature weight, b growth rate, $C$ age at maximum weight gain

\section{Diphasic logistic model}

The a1 value for GR1 males was obviously higher than those of the GR2 and GR3 groups when two stage logistic model was used $(P<0.05$, Table 3$)$. The a1 estimates for GR1 and GR2 females were close to each other and were obviously higher than that of the GR3. Weight at the end of phase $2(a 1+a 2)$ was higher for GR2 males than for GR3 and GR1 males. Weights at the end of phase 2 of GR3 and GR1 females were significantly higher than that of the GR2 females $(P<0.05)$. When weight gains (a2) were examined it was seen that the weight gains for GR2 males was higher than for GR3 and GR1. The a2 for GR3 females, on the other hand, was higher than those of the GR1 and GR2 females.

Growth rate estimates of GR1 males and females in the phase 1 (b1) were significantly higher than those of the GR2 and GR3 $(P<0.05)$. The b1 estimates for both sexes in GR1 were similar. While the b1 estimates for GR2 females was higher than that of the males, the b1 estimates for GR3 males was higher than that of the females. For phase 2, the growth rate estimates (b2) for GR2 and GR3 males were significantly higher than that of the GR1 $(P<0.05)$. On the other side, the b2 estimates of GR3 females were higher than those of the GR1 and GR2. Age at maximum weight gain (c2) was later for males than for females for each group. The C2 estimates for males in GR2 was obviously later than for females while the $\mathrm{c} 2$ estimates for both sexes were similar for GR1 and GR3. 
Table 3

Estimates of model parameters based on a diphasic logistic model

Schätzung der Modellparameter auf der Grundlage des zweiphasigen Logistikmodells

\begin{tabular}{lccccccc}
\hline Group & Sex & a1 & b1 & c1 & a2 & b2 & c2 \\
\hline \multirow{2}{*}{ GR1 } & Males & 813.7 & 7.42 & 21.9 & 2106.5 & 6.64 & 41.1 \\
& Females & 621.4 & 7.14 & 17.7 & 2317.1 & 7.33 & 39.8 \\
GR2 & Males & 95.8 & 3.17 & 16.7 & 3315.4 & 9.26 & 41.4 \\
& Females & 612.1 & 6.64 & 17.8 & 1757.3 & 6.14 & 37.9 \\
\multirow{2}{*}{ GR3 } & Males & 88.4 & 5.75 & 14.4 & 3251.8 & 9.84 & 43.1 \\
& Females & 95.3 & 4.55 & 14.6 & 2870.2 & 9.92 & 42.0 \\
\hline
\end{tabular}

GR1 $11 \mathrm{birds} / \mathrm{m}^{2}$, GR2 $17 \mathrm{birds} / \mathrm{m}^{2}, \quad$ GR3 $25 \mathrm{birds} / \mathrm{m}^{2}$, a asymptotic or mature weight, b growth rate, $c$ age at maximum weight gain

\section{Triphasic logistic model}

Table 4

Estimates of model parameters based on a triphasic logistic model

Schätzung der Modellparameter auf der Grundlage des dreiphasigen Logistikmodells

\begin{tabular}{lccccrccccc}
\hline Group & Sex & \multicolumn{1}{c}{ a1 } & \multicolumn{1}{c}{ b1 } & \multicolumn{1}{c}{ c1 } & \multicolumn{1}{c}{ a2 } & \multicolumn{1}{c}{ b2 } & \multicolumn{1}{c}{ c2 } & a3 & b3 & c3 \\
\hline \multirow{2}{*}{ GR1 } & Males & 22.7 & 1.18 & 10.9 & 123.5 & 3.01 & 17.3 & 3841.2 & 10.62 & 44.2 \\
& Females & 17.6 & 0.96 & 10.2 & 87.7 & 1.74 & 16.1 & 3372.4 & 10.42 & 42.8 \\
GR2 & Males & 953.2 & 7.63 & 23.7 & 882.5 & 3.86 & 36.4 & 266.4 & 1.21 & 42.4 \\
& Females & 748.9 & 7.15 & 20.3 & 1121.2 & 3.79 & 34.5 & 232.8 & 1.38 & 42.0 \\
\multirow{2}{*}{ GR3 } & Males & 909.1 & 7.67 & 25.3 & 160.9 & 3.10 & 31.2 & 1325.2 & 5.27 & 43.4 \\
& Females & 204.3 & 5.12 & 18.5 & 81.2 & 1.66 & 29.1 & 5682.2 & 12.08 & 55.2 \\
\hline
\end{tabular}

GR1 $11 \mathrm{birds} / \mathrm{m}^{2}$, GR2 $17 \mathrm{birds} / \mathrm{m}^{2}$, GR3 $25 \mathrm{birds} / \mathrm{m}^{2}$, a asymptotic or mature weight, b growth rate, $C$ age at maximum weight gain

Body weight at the end of phase 1 (a1) was found to be high for GR2 males and females than those of the GR3 and GR1 when triphasic logistic model was used $(P<0.05$; Table 4). The b1 estimates for GR2 and GR3 males were obviously higher than that of the GR1 males. For each group, the growth rate of males had higher than that of the females and this case been most obvious for GR3. Age at maximum weight gain (c1) was later for males than for females. For both males and females, weight at the end of phase $2(\mathrm{a} 1+\mathrm{a} 2)$ was higher for GR2 than for GR3 and for GR1. As to be noticed, the difference (1070$285.5=784.5 \mathrm{~g}$ ) of the asymptotic weight estimates at the end of second phase of male and female birds in GR3 group, was obviously more than those of the group of GR1(146.2-105.3=40.9 g) and GR2 (1870.1-1835.7=34.4 g). The a2 estimates of GR1 and GR3 females were close to each other and theirs values were significantly smaller than that of the GR2 females $(P<0.05)$. The b2 estimates of GR2 males and females were higher than that of the GR1 and GR3. For GR1 and GR3 groups, the growth rate of males had higher than that of the females while the growth rate of males and females of GR2 group were almost the same. Age at maximum weight gain (c2) was later for males than for females for each group. The age at maximum weight gain of GR2 and GR3 were obviously later both males and females than that of the GR1 group.

Growth took on different patterns in the groups and sexes at the end of phase 3. For males, weight at the end of phase $3(a 1+a 2+a 3)$ was higher for GR1 than that of the GR3 
and GR2 $(P<0.05)$. For females, however, weight at the end of phase 3 was higher for GR3 than those of the GR1 and GR2. The a3 estimates for GR3 was obviously higher than for GR1 and for GR2. When b3 estimates were examined it was seen that the b3 estimates of GR2 females was significantly smaller than that of the GR1 and GR3 $(P<0.05)$. The c3 estimates were generally similar except for GR3 females. Age at maximum weight gain was later for males than for females for GR1 while the age at maximum weight gain was later for females than for males for GR3.

\section{Discussion}

Significant differences were found between the estimations made by using monophasic growth model and by using multiphasic growth models. In the result of the estimations made by using monophasic growth model, it was seen that (except for GR3) the estimated mature weight (a), growth rate (b) and age at maximum weight gain (c) of males and females in the GR1 and GR2 groups were similar to each other. However, when the growth is defined by using both diphasic and triphasic models, too different results were obtained. Estimations of the parameters made by using both diphasic and triphasic models, displayed significant level of difference with respect to the different phases. By the motivation of these findings, it could be concluded that, defining the growth by using multiphasic growth models instead of monophasic growth models, displays more detailed and reliable results. In other words, because examining the growth by dividing it into different phases minimizes the deviations of the estimations, more detailed information could be obtained for the different growth periods. In order to generalize the results of the study, the body weight measurements must be made during longer lifetime period. By the motivation of the results of diphasic and triphasic growth models, placement of less number of birds per square meter advances the age at the maximum weight gain and, it can be concluded that birds might gain the maximum weight in earlier periods in the result of this procedure. BILGILI and HESS (1995) reported that body weight and feed conversion of birds were significantly improved when more space was supply to the birds. FEDDES et al. (2002) reported that when bird density was reduced body and carcass weights were decreased. CORNETTO et al. (2003) reported that the body weight at 98 days of age was significantly higher for Ostrich grown in the low density than that of the high density. Based on the results of this study it was possible to conclude that describing the growth by use of multiphasic growth models would yield more reliable results than monophasic models.

\section{References}

Bilgili SF, Hess JB (1995) Placement density influences broiler carcass grade and meat yields. J Appl Poultry Res 4, 384-9

Bock, RD, Thissen DM (1976) Fitting multi-component models for growth in stature. Proc of the 9th Biometric Conference, Boston, 431-42

Cornetto T, Angel R, Estevez I (2003) Influence of stocking density and dieaty energy on Ostrich (Struthio camelus) performance. Int J Poultry Sci 2,102-6

Çamdeviren H, Taşdelen B (2002) Mono and multiphasic analysis of growth curves selected of a Japanese auail line at 5-week's body weight. Turk J Vet Anim Sci 26, 421-7 
Ersoy IE, Mendeş M, Aktan S (2006) Growth curve establishment for american Bronze turkeys. Arch Tierz 49, 293-9

Feddes JJ, Emmanuel EJ, Zuidhof MJ (2002) Broiler performance, body weight variance, feed and water intake, and carcass quality at different stocking densities. Poultry Sci 81, 774-9

Grossman M, Koops WJ (1988) Multiphasic analysis of growth curves in chickens. Poultry Sci 67, 33-42

Hurwitz S, Talpaz H, Bartov I, Plevnik I (1991) Characterization of growth and development of male British United turkeys. Poultry Sci 70, 2419-24

Koenen EPC, Groen AF (1996) Genetic analysis of growth patterns of Black and White Dairy Heirfers. J Dairy Sci 79, 495-501

Koops WJ (1986) Multiphase growth curve analysis. Growth 50, 169-77

Koops WJ, Grossman M, Mighalska E (1987) Multiphase growth curve analysis in mice. Growth 51, 372-82

Koops WJ, Grossman M (1991) Application of a multiphasic growth function to body composition in pigs. J Anim Sci 69, 3265-73

Mendeş M, Dinçer E, Arslan E (2007) Profile Analysis and growth curve for body mass index of broiler chickens reared under different feed restrictions in early age. Arch Tierz 50, 403-11

Peil J, Helwin H (1981) A phenomenologic-mathematical model of growth dynamics. Biom J 23, 41-54

Piantadosi S (1987) Generalizing growth functions assuming parameter heterogeneity. Growth 51, 50

SAS (1999) SAS OnlineDoc, Version 8, Cary, NC, USA

Søransen K, Grossman M, Koops WJ (2003) Multiphasic growth curves in Mink (Mustela vision) selected for feed efficiency. Acta Agric Scand, Sect A Animal Sci 53, 41-50

Wellockt IJ, Emmans GC, Kyriazakis I (2004) Describing and predicting potential growth in the pig. Animals Sci 78, 379-88

Received 17 November 2008, accepted 18 November 2009.

Corresponding author:

MEHMET MENDEŞ

email: mmendes@comu.edu.tr

Biometry and Genetic unit 17020, Department of Animal Science, Faculty of Agriculture, Canakkale Onsekiz Mart University, Canakkale, Turkey, Çanakkale, Turkey 